\title{
The C825T polymorphism in the G-protein $\beta 3$ subunit gene and diabetic complications in IDDM patients
}

Received: July 14, 2000 / Accepted: January 4, 2001

\begin{abstract}
Complications of insulin-dependent diabetes mellitus (IDDM) are a major cause of morbidity and mortality; however, the mechanisms of their development are still to be elucidated. Genetic susceptibility contributes to the pathogenesis of nephropathy in IDDM. Enhanced Gprotein activation, a cellular phenotype observed in cultured cells from patients with essential hypertension, was recently documented in IDDM subjects with nephropathy. A C825T polymorphism was recently described in $G N B 3$, the gene encoding the beta 3 subunit of heterotrimeric G-proteins. This genetic variant has been associated with enhanced Gprotein activation. The $825 \mathrm{~T}$ allele was observed more frequently in a group with essential hypertension. We analyzed the role of the C825T polymorphism in the predisposition to diabetic complications in IDDM. In this study, we investigated the frequency of this polymorphism in a large casecontrol study and found no association of the 825T allele with diabetic nephropathy, retinopathy, and neuropathy.
\end{abstract}

Key words Genetic predisposition to disease $\cdot G N B 3 \cdot$ Diabetic nephropathy $\cdot$ Diabetic retinopathy $\cdot$ Diabetic neuropathy $\cdot$ Diabetes mellitus $\cdot$ Insulin-dependent

\section{Introduction}

Insulin-dependent diabetes mellitus (IDDM) is characterized by a high prevalence of late diabetic complications such as nephropathy, retinopathy, neuropathy, and macroangiopathy. Genetic differences may contribute to differences in the development of diabetic complications, as previously suggested for nephropathy (Quinn et al. 1996). Diabetic nephropathy is related to a predisposition to essential hypertension (Fogarty and Krolewski 1997). Siffert

N.S. Shcherbak $(\bowtie) \cdot$ E.I. Schwartz

Laboratory of Molecular Cardiology, St. Petersburg State Medical

University, L. Tolstoy St. 6/8, St. Petersburg 197189, Russia

Tel./Fax +1-603-297-2893

e-mail: nshch@yahoo.com et al. (1995) demonstrated enhanced signal transduction via pertussis toxin-sensitive G-proteins in lymphoblasts and fibroblasts from selected patients with essential hypertension. Enhanced G-protein activation has been shown in immortalized B-lymphoblast cell lines from diabetic nephropathy patients compared with findings in diabetic patients without nephropathy (Pietruck et al. 1998). G-protein is a heterotrimeric protein that consists of alpha, beta, and gamma subunits. The structural changes in subunits of Gproteins could be responsible for the enhanced G-protein activity.

A polymorphism, C825T, was detected in exon 10 of the GNB3 gene on chromosome 12p13, encoding the $\beta 3$ subunit of heterotrimeric G-proteins (Siffert et al. 1998). The T allele was associated with the occurrence of a splice variant in which the nucleotides 498-620 of exon 9 are deleted. As a result, 41 amino acids from the $\mathrm{G}_{\beta}$ subunit are lost. The $\mathrm{T}$ allele of the GNB3 gene was observed more frequently in a group with hypertension in unselected German patients (frequency, 0.31 versus 0.25 in the controls; Siffert et al. 1998) but a similar association was not observed in the Japanese population (Kato et al. 1998). The frequency of the GNB3 825T allele was 0.501 in Canadian Oji-Cree, which is considerably higher than the frequency observed in whites (Hegele et al. 1998).

Furthermore, genetic variation of the GNB3 nucleotide 825 was significantly associated with variation in systolic pressure but not diastolic pressure (Hegele et al. 1998). The frequency of the minor allele $(\mathrm{T})$ was 0.25 in a normotensive group and 0.43 in a hypertensive group in an Australian white population (Benjafield et al. 1998). Schunkert et al. (1998) demonstrated an association between the 825T allele and lower renin and elevated diastolic blood pressure levels. Recently, an association was shown between the 825T allele and obesity in Caucasian, Chinese, and African individuals (Siffert et al. 1999), while the 825T allele was also reported to be associated with left ventricular hypertrophy in hypertensive patients (Poch et al. 2000) and with impaired left ventricular diastolic filling in hypertensive subjects (Jacobi et al. 1999). Fogarty et al. (1998) investigated the role of the C825T polymorphism in GNB3 in the predis- 
position to diabetic nephropathy in type I diabetes. The $\mathrm{T}$ allele showed no association with diabetic nephropathy.

In the present study, we investigated the C825T allele status in IDDM patients in a Russian population. We have been interested in the role of the $825 \mathrm{~T}$ allele in the development of diabetic complications in patients with IDDM.

\section{Patients and methods}

\section{Patients}

The subjects of this study had participated in the program "Diabetes" (which included the monitoring of trends, and examination of the determinants of vascular complications in IDDM) carried out in St. Petersburg, Russia, since 1997.

We studied 515 IDDM subjects (250 male; 265 female) aged 2-62 years (mean age, $16.8 \pm 10.6$ years) with a history of IDDM of 1 to 40 years, duration (mean duration, $8.5 \pm$ 7.3 years). The diabetic patients included in this study fulfilled the World Health Organization criteria for diabetes mellitus (Diabetes Mellitus, 1985). At entry, the patients had glycated haemoglobin $\left(\mathrm{HbA}_{1 \mathrm{c}}\right)$ levels of $5.7 \%$ to $16.8 \%$.

Among the IDDM patients with diabetes duration of 5 years or more, we selected groups with diabetic complications and those without complications. Diabetic nephropathy status in patients with type 1 diabetes was determined on the basis of questionnaires, medical records, and measurements of albumin excretion. Patients receiving treatment for renal disease, those with persistent proteinuria, or those with persistent high albuminuria (after review of all information for evidence of nondiabetic renal disease) were considered to have diabetic nephropathy. Persistent proteinuria was diagnosed when two out of three sequential urinalyses were positive for protein (albumin excretion, more than $300 \mathrm{mg} /$ daily). Persistent high albuminuria was diagnosed if albumin excretion was more than $30 \mathrm{mg} /$ daily in two out of three urinalyses. Individuals with no history of nephropathy and no albumin excretion were considered to be free of nephropathy. The diagnosis of retinopathy was based upon fundus ophthalmoscopy and angiofluorography. The diabetic retinopathy group consisted of those showing retinal change, while the IDDM control group was defined as those patients having no signs of retinopathy. Absence or presence of neuropathy was defined according to criteria consisting of signs, and symptoms including numbness, dysesthesias and/or paraesthesias, hypersensitivity to touch, burning pain and/or aching, stabbing pain in hands and/or feet, and neuropathic foot ulcer, and decreased or absent deep tendon reflexes.

Patients who did not meet the criteria of any of these categories were considered unsuitable for classification and were excluded from the study.

The IDDM group with nephropathy consisted of 74 subjects. The IDDM group without nephropathy $(n=92)$ had normoalbuminuria. The IDDM groups with and without retinopathy consisted of 76 and 96 subjects, respectively. The IDDM group with neuropathy consisted of 50 subjects, and the group without neuropathy consisted of 154 individuals. Some subjects had more than one type of diabetic complication, and, consequently, were analyzed in more than one group.

All subjects who participated in this study were Russian. Albuminuria and $\mathrm{HbA}_{1 \mathrm{c}}$ were assessed by standard laboratory techniques.

\section{DNA genotyping}

DNA was isolated from whole blood by a modified phenolchloroform method (Kunkel et al. 1977; Lahiri et al. 1992). The C825T polymorphism of the GNB3 gene was detected by polymerase chain reaction (PCR). PCR was performed with the primers: 5'-TGACCCACTTGCCACCCGTGC$3^{\prime}$ (sense) and 5'-GCAGCAGCCAGGGCTGGC-3' (antisense) (Siffert et al. 1998). A denaturation step at $94^{\circ} \mathrm{C}$ for $5 \mathrm{~min}$ was followed by 35 cycles of denaturation at $94^{\circ} \mathrm{C}$ $(1 \mathrm{~min})$, annealing at $62^{\circ} \mathrm{C}(1 \mathrm{~min})$, extension at $72^{\circ} \mathrm{C}(1 \mathrm{~min})$, and a final extension at $72^{\circ} \mathrm{C}(10 \mathrm{~min})$, using a MiniCycler (MJ Research, Watertown, MA, USA). The PCR products were digested with $B s e \mathrm{D} 1$ (Fermentas, Vilnius, Lithuania), separated on $8 \%$ acrylamide gels, and visualized under UV illumination after ethidium bromide staining. The undigested product (TT genotype) has a size of $268 \mathrm{bp}$; complete digestion (CC genotype) results in bands of 116 and $152 \mathrm{bp}$, respectively (Siffert et al. 1998).

\section{Statistical analysis}

All data values are given as means \pm SD. Genotypes and allele frequencies in controls and other subjects were compared using standard $\chi^{2}$ tests. Normally distributed continuous variables were compared by one-way analysis of variance (ANOVA), and the Kruskal-Wallis test was used for the comparison of nonnormally distributed variables. Differences were regarded as significant at $P$ values of less than 0.05 .

\section{Results}

Clinical characteristics according to study groups are shown in Table 1. In the IDDM group overall and in the subgroups, the genotype distribution was in Hardy-Weinberg equilibrium, and did not differ between males and females.

Table 2 shows a comparison of demographic variables among the CC, CT, and TT subsets. None of the parameters (including age, sex, diabetes duration, and age at diabetes onset) showed significant differences between the CC, CT, and TT genotype groups. The frequency of the GNB3 825T allele was 0.29 in the IDDM group overall.

The distribution of the GNB3 genotypes is shown in Table 3. There was no significant difference in the frequency of the three genotypes between groups with complications and groups without complications. There were no 
Table 1. Clinical characteristics by study group

\begin{tabular}{|c|c|c|c|c|c|c|}
\hline & $\begin{array}{l}\text { IDDM } \\
\text { subjects } \\
\text { with } \\
\text { nephropathy } \\
(\mathrm{DN}+)\end{array}$ & $\begin{array}{l}\text { IDDM } \\
\text { subjects } \\
\text { without } \\
\text { nephropathy } \\
(\mathrm{DN}-)\end{array}$ & $\begin{array}{l}\text { IDDM } \\
\text { subjects } \\
\text { with } \\
\text { retinopathy } \\
(\mathrm{DR}+)\end{array}$ & $\begin{array}{l}\text { IDDM } \\
\text { subjects } \\
\text { without } \\
\text { retinopathy } \\
(\mathrm{DR}-)\end{array}$ & $\begin{array}{l}\text { IDDM } \\
\text { subjects } \\
\text { with } \\
\text { neuropathy } \\
(\mathrm{DNP}+)\end{array}$ & $\begin{array}{l}\text { IDDM } \\
\text { subjects } \\
\text { without } \\
\text { neuropathy } \\
\text { (DNP-) }\end{array}$ \\
\hline$n$ & 74 & 92 & 76 & 96 & 50 & 154 \\
\hline Age (years) & $25.1 \pm 11.9$ & $20.8 \pm 8.7$ & $29.8 \pm 10.1$ & $22.9 \pm 9.1$ & $28.8 \pm 12.5$ & $24.5 \pm 9.9$ \\
\hline Sex (male/female) & $30 / 44$ & $42 / 50$ & $31 / 45$ & $41 / 55$ & $22 / 28$ & $73 / 81$ \\
\hline Diabetes duration (years) & $14.8 \pm 8.8$ & $10.9 \pm 4.3$ & $17.4 \pm 8.6$ & $11.2 \pm 3.1$ & $17.2 \pm 9.5$ & $12.4 \pm 4.9$ \\
\hline $\mathrm{HbA}_{1 \mathrm{c}}(\%)$ & $10.5 \pm 2.2$ & $9.8 \pm 1.9$ & $10.6 \pm 1.7$ & $9.9 \pm 1.7$ & $10.1 \pm 1.5$ & $9.7 \pm 1.9$ \\
\hline
\end{tabular}

Data values are means \pm SD

IDDM, Insulin-dependent diabetes mellitus; $\mathrm{HbA}_{1 \mathrm{c}}$, glycated haemoglobin

Table 2. Demographics according to GNB3 genotype

\begin{tabular}{lllll}
\hline & \multicolumn{2}{l}{ Genotype } & \\
\cline { 2 - 4 } Variable & CC & CT & TT & $P$ \\
\hline$n$ & 259 & 214 & 42 & \\
Age (years) & $16.3 \pm 8.3$ & $17.4 \pm 8.6$ & $17.6 \pm 6.8$ & $0.45^{\text {a }}$ \\
Sex (no. of males) & 132 & 109 & 24 & $0.41^{\text {b }}$ \\
Diabetes duration (years) & $7.3 \pm 6.1$ & $7.5 \pm 5.8$ & $7.8 \pm 5.2$ & $0.77^{\mathrm{c}}$ \\
Age at diabetes onset (years) & $8.6 \pm 5.2$ & $9.4 \pm 5.1$ & $9.1 \pm 4.1$ & $0.21^{\mathrm{a}}$ \\
HbA $_{1 \mathrm{c}}(\%)$ & $10.2 \pm 3.9$ & $9.4 \pm 2.5$ & $8.9 \pm 1.9$ & $0.12^{\mathrm{c}}$ \\
\hline
\end{tabular}

Data values are means $\pm \mathrm{SD}$

${ }^{\mathrm{a}}$ One-way analysis of variance (ANOVA)

${ }^{\mathrm{b}} \chi^{2}$ test

${ }^{\mathrm{c}}$ Kruskal-Wallis test

Table 3. Distribution of GNB3 C825T alleles and genotypes in case-control association study

\begin{tabular}{|c|c|c|c|c|c|c|}
\hline & $\begin{array}{l}\text { IDDM } \\
\text { subjects } \\
\text { with } \\
\text { nephropathy } \\
(\mathrm{DN}+) \\
n(\%)\end{array}$ & $\begin{array}{l}\text { IDDM } \\
\text { subjects } \\
\text { without } \\
\text { nephropathy } \\
(\mathrm{DN}-) \\
n(\%)\end{array}$ & $\begin{array}{l}\text { IDDM } \\
\text { subjects } \\
\text { with } \\
\text { retinopathy } \\
(\mathrm{DR}+) \\
n(\%)\end{array}$ & $\begin{array}{l}\text { IDDM } \\
\text { subjects } \\
\text { without } \\
\text { retinopathy } \\
\text { (DR-) } \\
n(\%)\end{array}$ & $\begin{array}{l}\text { IDDM } \\
\text { subjects } \\
\text { with } \\
\text { neuropathy } \\
\text { (DNP+) } \\
n(\%)\end{array}$ & $\begin{array}{l}\text { IDDM } \\
\text { subjects } \\
\text { without } \\
\text { neuropathy } \\
(\mathrm{DNP}-) \\
n(\%)\end{array}$ \\
\hline Allele C & $102(69)$ & $135(73)$ & $100(66)$ & $135(70)$ & $67(67)$ & $214(69)$ \\
\hline Allele T & $46(31)$ & $49(27)$ & $52(34)$ & $57(30)$ & $33(33)$ & $94(31)$ \\
\hline Total number of chromosomes & & 184 & 152 & 192 & \multirow{2}{*}{\multicolumn{2}{|c|}{$\chi^{2}(1 \mathrm{df})=0.23, P>0.05$}} \\
\hline & \multicolumn{2}{|c|}{$\chi^{2}(1 \mathrm{df})=0.95, P>0.05$} & \multicolumn{2}{|c|}{$\chi^{2}(1 \mathrm{df})=0.86, P>0.05$} & & \\
\hline Genotype CC & $34(46)$ & $50(54)$ & $31(41)$ & $48(50)$ & $22(44)$ & $76(50)$ \\
\hline Genotype CT & $34(46)$ & $35(38)$ & $38(50)$ & $39(41)$ & $23(46)$ & $62(40)$ \\
\hline Genotype TT & $6(8)$ & $7(8)$ & $7(9)$ & $9(9)$ & $5(10)$ & $16(10)$ \\
\hline \multirow[t]{2}{*}{ Total number of subjects } & 74 & 92 & 76 & 96 & 50 & 154 \\
\hline & \multicolumn{2}{|c|}{$\chi^{2}(2 \mathrm{df})=0.95, P>0.05$} & \multicolumn{2}{|c|}{$\chi^{2}(2 \mathrm{df})=1.66, P>0.05$} & \multicolumn{2}{|c|}{$\chi^{2}(2 \mathrm{df})=0.46, P>0.05$} \\
\hline
\end{tabular}

df, Degrees of freedom

observed differences in the frequency of the $825 \mathrm{~T}$ allele between any groups.

Combining of the genotype groups, based on the presence of at least one $825 \mathrm{~T}$ allele, also showed no significant differences between groups (data not shown).

\section{Discussion}

In this study, we have elucidated the role of the C825T polymorphic variant of the GNB3 gene in the predisposition to diabetic complications. Siffert et al. (1995), in a previous study, showed enhanced signal transduction via pertussis toxin-sensitive G-proteins in lymphoblasts and fibroblasts from selected patients with essential hypertension. In a later report, the C825T polymorphism of the GNB3 gene was found to be associated with essential hypertension (Siffert et al. 1998). Recently, Pietruck et al. (1998) demonstrated enhanced G-protein activation in IDDM patients with diabetic nephropathy. Considering these findings, Fogarty et al. (1998) speculated that this genetic variant (i.e., the C825T polymorphism of the GNB3 gene) associated with essential hypertension, possibly increases susceptibility to diabetic nephropathy. 
We suggested that the C825T polymorphism in the GNB3 gene may be associated with diabetic complications. In our investigation, no association of the minor $\mathrm{T}$ allele of the GNB3 gene with diabetic nephropathy was demonstrated. This result for diabetic nephropathy confirms the findings of Fogarty et al. (1998). The T allele frequency in our group with diabetic nephropathy was 0.31 , which is almost identical to the frequency (0.32) observed by Fogarty et al. (1998). In the present study, the age and duration of diabetes in our diabetic nephropathy patients were less than the age and duration of diabetes in the patients investigated by Fogarty et al. (1998).

In the present study, we also analyzed the association of the $825 \mathrm{~T}$ allele with diabetic retinopathy and neuropathy, but we found no significant differences between groups with and without these complications.

In conclusion, the present study found no evidence for a role of the T allele of the GNB3 gene in the genetic susceptibility to diabetic complications in IDDM patients.

Acknowledgments This work was supported by the St. Petersburg Diabetic Center (Russia). The authors thank Dr. A.S. Stroikova for her valuable consultation and verification of patients' clinical information.

\section{References}

Benjafield AV, Jeyasingam CL, Nyholt DR, Griffiths LR, Morris BJ (1998) G-protein beta3 subunit gene (GNB3) variant in causation of essential hypertension. Hypertension 32:1094-1097

Diabetes mellitus (1985) WHO Technical Report Series, 727. World Health Organization, Geneva

Fogarty DG, Krolewski AS (1997) Genetic susceptibility and the role of hypertension in diabetic nephropathy. Curr Opin Nephrol Hypertens 8:37-39

Fogarty DG, Zychma MJ, Scott LJ, Warram JH, Krolewski AS (1998) The C825T polymorphism in the human G-protein beta3 subunit gene is not associated with diabetic nephropathy in Type I diabetes mellitus. Diabetologia 41:1304-1308
Hegele RA, Harris SB, Hanley AJ, Cao H, Zinman B (1998) G protein beta3 subunit gene variant and blood pressure variation in Canadian Oji-Cree. Hypertension 32:688-692

Jacobi J, Hilgers KF, Schlaich MP, Siffert W, Schmieder RE (1999) $825 \mathrm{~T}$ allele of the G-protein beta3 subunit gene (GNB3) is associated with impaired left ventricular diastolic filling in essential hypertension. J Hypertens 17:1457-1462

Kato N, Sugiyama T, Morita H, Kurihara H, Yamori Y, Yazaki Y (1998) G-protein beta3 subunit variant and essential hypertension in Japanese. Hypertension 32:935-938

Kunkel LM, Smith KD, Boyer SH, Borgaonkar DS, Wachtel SS, Miller OJ, Breg WR, Jones HW Jr, Rary JM (1977) Analysis of human Ychromosome-specific reiterated DNA in chromosome variants. Proc Natl Acad Sci USA 74:1245-1249

Lahiri DK, Bye S, Nurnberger JI Jr, Hodes ME, Crisp M (1992) A nonorganic and non-enzymatic extraction method gives higher yields of genomic DNA from whole-blood samples than do nine other methods tested. J Biochem Biophys Methods 25:193-205

Pietruck F, Spleiter S, Daul A, Philipp T, Derwahl M, Schatz H, Siffert W (1998) Enhanced G-protein activation in IDDM patients with diabetic nephropathy. Diabetologia 41:94-100

Poch E, Gonzalez D, Gomez-Angelats E, Enjuto M, Pare JC, Rivera F, de La Sierra A (2000) G-Protein beta(3) subunit gene variant and left ventricular hypertrophy in essential hypertension. Hypertension 35(1 Pt 2):214-218

Quinn M, Angelico MC, Warram JH, Krolewski AS (1996) Familial factors determine the development of diabetic nephropathy in patients with IDDM. Diabetologia 39:940-945

Schunkert H, Hense HW, Doring A, Riegger GA, Siffert W (1998) Association between a polymorphism in the $G$ protein beta3 subunit gene and lower renin and elevated diastolic blood pressure levels. Hypertension 32:510-513

Siffert W, Rosskopf D, Moritz A, Wieland T, Kaldenberg-Stasch S, Kettler N, Hartung K, Beckmann S, Jakobs KH (1995) Enhanced G protein activation in immortalized lymphoblasts from patients with essential hypertension. J Clin Invest 96:759-766

Siffert W, Rosskopf D, Siffert G, Busch S, Moritz A, Erbel R, Sharma AM, Ritz E, Wichmann HE, Jakobs KH, Horsthemke B (1998) Association of a human G-protein beta3 subunit variant with hypertension. Nat Genet 18:45-48

Siffert W, Forster P, Jockel KH, Mvere DA, Brinkmann B, Naber C, Crookes R, Du P Heyns A, Epplen JT, Fridey J, Freedman BI, Muller N, Stolke D, Sharma AM, Al Moutaery K, Grosse-Wilde H, Buerbaum B, Ehrlich T, Ahmad HR, Horsthemke B, Du Toit ED, Tiilikainen A, Ge J, Wang Y, Yang D, Hüsing J, Rosskopf D (1999) Worldwide ethnic distribution of the $\mathrm{G}$ protein beta3 subunit $825 \mathrm{~T}$ allele and its association with obesity in Caucasian, Chinese, and Black African individuals. J Am Soc Nephrol 10:1921-1930 